\title{
Problem-based learning: application and possibilities in Brazil
}

\author{
Escola de Saúde Pública do Ceará - Ceará, Brasil
}

\begin{abstract}
The Ministry of Health launched the Family Health Program (FHP) with the aim of establishing comprehensive primary care for families and communities. The Public Health School of Ceará has been applying problem-based learning as the instructional method for the training of the family health teams. The importance of this method and the possibility of applying it in the implementation of a new and effective approach to the continuing education of Brazilian health professionals are emphasized.
\end{abstract}

Uniterms: Problem-based learning. Continuing medical education. Teaching methods.

$\mathrm{T}$ The Brazilian Ministry of Health launched its Family Health Programme (FHP) ${ }^{(1)}$ in 1994, with the aim of establishing comprehensive primary health care for families and communities. FHP is carried out by a team (the Family Health Team - FHT) composed of at least one medical doctor, one nurse and eight community health workers, living preferentially in the community to which they are allocated. The FHT should assume the responsibility of providing continuous primary care to 1000 families, via a broad range of activities related to health promotion.

The Health Secretariat of the State of Ceará (HSSC) has formally defined the FHP as a priority project. Consequently, most Ceará municipalities have implemented the FHP and some health indicators are

\section{Address for correspondence:}

João Macedo Coelho-Filho

Rua Professor Costa Mendes, 1608 - 4º Andar.

Fortaleza/CE, Brasil - CEP 60430-140 beginning to improve, such as a reduction in the number of referrals to hospitals.

However, the lack of professionals with the knowledge and skills necessary to perform the new tasks required by the family health practices is thought to be a constraint on the achievement of greater impact by the FHP.

In 1996, the Public Health School of Ceará (PHSC), the institution charged with the continuing education of Ceará health system professionals, took on the task of training the FHTs that were already working in the field. From this starting point, a course for medical doctors and nurses engaged in the FHTs was designed. The design followed the educational approach adopted by the PHSC, which is based on the concept of "community-oriented education", ${ }^{2}$ and problem-based learning (PBL) was chosen as the instructional method.

PBL is a student-centered approach to learning in which a small group meets to analyze, explain and solve a problem. In PBL the students should formulate their own learning objectives and select the learning resources through pertinent 
literature search. ${ }^{3} \mathrm{PBL}$, a methodology linked to the teaching of Evidence-Based Medicine (EBM), is found in various distinguished international medical schools, and it has just been implemented in some Brazilian educational institutions.

To date, a number of FHTs has been trained with PBL at the PHSC, involving facilitators who also are faculty members from the Federal University of Ceará School of Medicine. It is known that PBL methodology increases the participants' ability to solve real-life problems, compared with traditional instruction, as well as improving interpersonal skills, the ability to reason, and the self-motivation to learn. ${ }^{4}$ These achievements are crucial for the FHTs, since they are composed of

\section{REFERENCES}

1. Brazil. The Family Health Program: health into the home. Brasilia: National Health Foundation, Ministry of Health 1994:6-10.

2. Magzoub ME. Studies on community-based education: program implementation and student assessment at the professionals who are already coping with real situations, developing group activities, and living far from formal health educational centers.

PHSC has also applied PBL to other types of training, such as that aimed at health managers in Ceará municipalities. Indeed, a statewide problem-based EBM training programme is currently being proposed, in cooperation with the medical associations and the Federal University of Ceará School of Medicine.

Thus, this experience from Ceará suggests that PBL would be an important strategy in the implementation of a new and effective educational approach for health professionals in Brazil.

Faculty of Medicine, University of Gezira, Sudan. Maastricht: Universitaire Drukkerij 1994.

3. Schmidt HG. Problem-based learning: rationale and description. Medical Education 1983; 17:11-6.

4. Albanese M, Mitchell S. Problem-based learning: a review of literature on its outcomes and implementation issues. Academic Medicine 1993;68(1):52-81.

\section{Resumo}

O Ministério da Saúde lançou em 1994 o Programa Saúde da Família (PSF), objetivando estabelecer atenção primária ampla para famílias e comunidades. Equipes do PSF vêm sendo treinadas pela Escola de Saúde Pública do Ceará através de Metodologia de Aprendizagem Baseada em Problemas (Problem-based Learning), ressaltando-se aqui a importância deste método e a possibilidade de aplicá-lo como estratégia de implementação de um novo e efetivo processo de educação dos profissionais de saúde no Brasil. 